\title{
Pemutusan Rantai Penularan Covid-19 Pada Ibu Hamil, Nifas dan Menyusui di Kecamatan Ratu Agung Kota Bengkulu
}

\author{
Yetti Purnama $^{1}$, Kurnia Dewiani ${ }^{2}$, Linda Yusanti ${ }^{3}$ \\ ${ }^{123}$ Prodi D3 Kebidanan FMIPA Universitas Bengkulu \\ E-mail: ypurnama@unib.ac.id
}

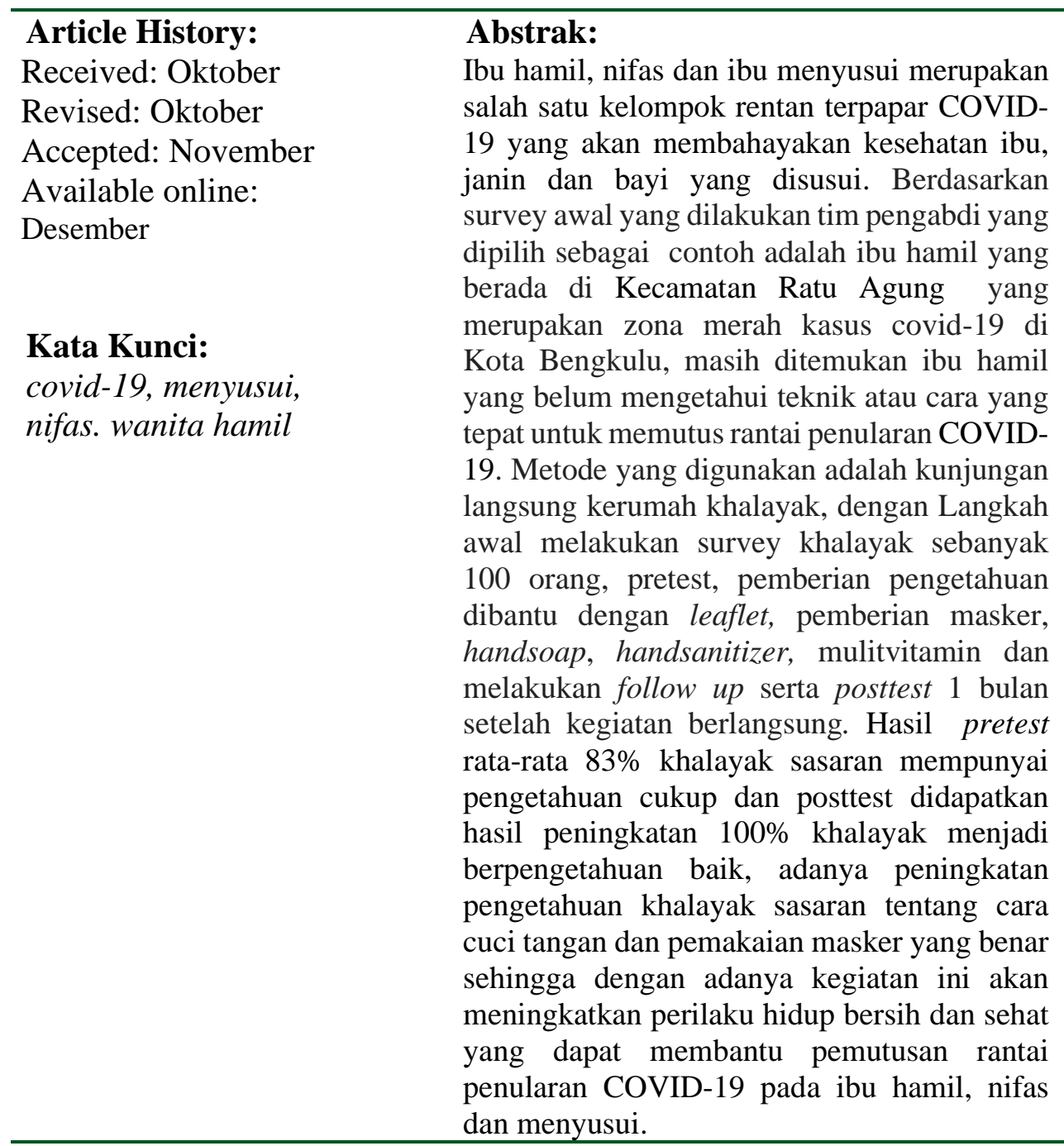




\section{Pendahuluan}

Coronavirus adalah keluarga besar virus yang menyebabkan penyakit mulai dari gejala ringan sampai berat. Coronavirus Disease 2019 (COVID-19) adalah penyakit jenis baru yang belum pernah diidentifikasi sebelumnya pada manusia. Virus penyebab COVID-19 ini dinamakan Sars-CoV-2. Virus corona adalah zoonosis (ditularkan antara hewan dan manusia). Adapun, hewan yang menjadi sumber penularan COVID-19 ini masih belum diketahui secara pasti. COVID-19 sedang mewabah di seluruh dunia saat ini dan menjadi pandemi global telah berdampak serius pada sendi-sendi ekonomi dan kesehatan masyarakat.

Infeksi COVID-19 dapat menimbulkan gejala ringan, sedang atau berat. Gejala klinis utama yang muncul yaitu demam ( $\operatorname{suhu}>38^{\circ} \mathrm{C}$ ), batuk dan kesulitan bernapas. Selain itu dapat disertai dengan sesak memberat, fatigue, mialgia, gejala gastrointestinal seperti diare dan gejala saluran napas lain. Setengah dari pasien timbul sesak dalam satu minggu. Pada kasus berat perburukan secara cepat dan progresif, seperti ARDS, syok septik, asidosis metabolik yang sulit dikoreksi dan perdarahan atau disfungsi sistem koagulasi dalam beberapa hari. Pada beberapa pasien, gejala yang muncul ringan, bahkan tidak disertai dengan demam, kebanyakan pasien memiliki prognosis baik, dengan sebagian kecil dalam kondisi kritis bahkan meninggal.

Indonesia sudah menjadi salah satu negara pandemi COVID-19. Jumlah kasus positif setiap hari semakin mengalami peningkatan. Pada tanggal 09 April 2020 kasus positif sebanyak 3.293, kasus meninggal dunia 280, sembuh 252 dan sebanyak 33 provinsi sudah berada di zona merah. Data di Provinsi Bengkulu total yang terkonfimasi positif COVID-19berjumlah 4 orang dan semua berada di wilayah Kota Bengkulu, dengan kasus konfirmasi dirawat di RS 1 orang, kasus konfirmasi meninggal dunia 1 orang dan isolasi mandiri sebanyak 2 orang berada di wilayah Kecamatan Ratu Agung Kota Bengkulu.

Ibu hamil, bersalin, nifas dan bayi baru lahir merupakan salah satu kelompok rentan terpapar COVID-19, ibu hamil memiliki risiko lebih tinggi terjangkit penyakit berat, morbiditas dan mortalitas dibandingkan dengan populasi umum. Efek samping pada janin berupa persalinan preterm juga dilaporkan pada ibu hamil dengan infeksi COVID-19. Akan tetapi informasi ini sangat terbatas dan belum jelas apakah komplikasi ini mempunyai 
hubungan dengan infeksi pada ibu. Dalam dua laporan yang menguraikan 18 kehamilan dengan COVID-19, semua terinfeksi pada trimester ketiga didapatkan temuan klinis pada ibu hamil mirip dengan orang dewasa yang tidak hamil. Gawat janin dan persalinan prematur ditemukan pada beberapa kasus. Pada dua kasus dilakukan persalinan sesar dan pengujian untuk SARSCoV-2 ditemukan negatif pada semua bayi yang diperiksa.

Banyak upaya telah dilakukan untuk memutus rantai penularan virus COVID-19. Prinsip-prinsip pencegahan/pemutusan rantai penularan COVID19pada ibu hamil, ibu nifas dan bayi baru lahir di masyarakat meliputi universal precaution yaitu sama dengan pencegahan pada masyarakat umumnya dengan selalu cuci tangan memakai sabun selama 20 detik atau hand sanitizer, pemakaian alat pelindung diri (masker kain), menjaga kondisi tubuh dengan rajin olah raga dan istirahat cukup, makan dengan gizi yang seimbang, dan mempraktikan etika batuk-bersin, dan sebelum melakukan pemeriksaan kehamilan, persalinan dan nifas maka ibu harus membuat janji terlebih dahulu kepada bidan/dokter untuk kedatangan pemeriksaan, hal ini dimaksudkan agar ibu tidak terkontak dengan banyak orang di pelayanan kesehatan.

Berdasarkan masalah yang dijelaskan di atas membutuhkan peran kita sebagai masyarakat untuk memutus rantai penularan COVID-19 pada ibu hamil dan ibu menyusui. Bidan harus mampu memberikan asuhan kebidanan yang konsisten, berdasarkan evidance based dalam memberikan dukungan pada setiap ibu dalam proses kehamilan, persalinan dan masa nifas. Bidan mampu merencanakan asuhan yaitu pencegahan dan penanganan tepat yang dapat diberikan pada ibu sesuai dengan kebutuhan masa kehamilan, bersalin dan nifas dalam memutus rantai penularan Covid-19.

Berdasarkan survey awal yang dilakukan tim pengabdi yang dipilih sebagai contoh adalah 10 orang ibu hamil yang berada di Kecamatan Ratu Agung Kota Bengkulu dengan tiga Puskesmas (Puskesmas Nusa Indah, Sawah Lebar dan Lempuing). Terdapat 6 orang ibu hamil belum mengetahui teknik atau cara yang tepat untuk mencegah penularan COVID-19pada kehamilan dan bayi yang dikandungnya, dengan demikian tim pengabdi akan memberikan pengetahuan untuk pemutusan rantai penularan Corona Virus 
Disease 2019 (Covid-19) pada ibu hamil, nifas dan menyusui di Kecamatan Ratu Agung Kota Bengkulu

\section{Metode}

Metode yang digunakan dalam pengabdian ini menggunakan metode pendidikan kesehatan langsung ke khalayak sasaran sejumlah 100 ibu hamil, nifas, dan menyusui dengan dibantu oleh tenaga kesehatan/bidan yang bekerja di Puskesmas dan Praktik mandiri dalam wilayah Kecamatan Ratu Agung Kota Bengkulu. Langkah-langkah pokoknya adalah dimulai dengan mensurvey identitatas khalayak sasaran, melakukan pretest untuk mengetahui baseline pengetahuan mereka mengenai cara pemutusan rantai penularan COVID-19 pada kehamilan dan bayi yang dikandungnya, pada ibu nifas menyusui dan bayinya, Menjelaskan materi tentang cara pemutusan rantai penularan COVID-19 dengan bantuan media leaflet, Memberi kesempatan peserta untuk bertanya, membagikan masker, handsoap, handsanitizer, vitamin dan nutrisi secara langsung kepada khalayak sasaran, Melakukan evaluasi dan penguatan pengetahuan tentang materi yang disampaikan. Follow up secara langsung ke khalayak sasaran dalam waktu 1 bulan setelah implementasi untuk mendata dan mengobservasi kembali teknik cuci tangan dan pemakaian masker dan apakah setelah kegiatan ada masalah yang dihadapi khalayak sasaran terkait dengan pemutusan rantai penularan COVID19.

\section{Hasil}

Realisasi hasil pelaksanaan kegiatan pengabdian, fokus pada apa yang berubah dengan khalayak sasaran ketika sebelum dilakukan pengabdian dengan setelah adanya pengabdian, termasuk foto-foto kegiatan, data-data hasil yang diperoleh selama pengabdian, hambatan-hambatan yang dihadapi selama pelaksanaan kegiatan pengabdian. 


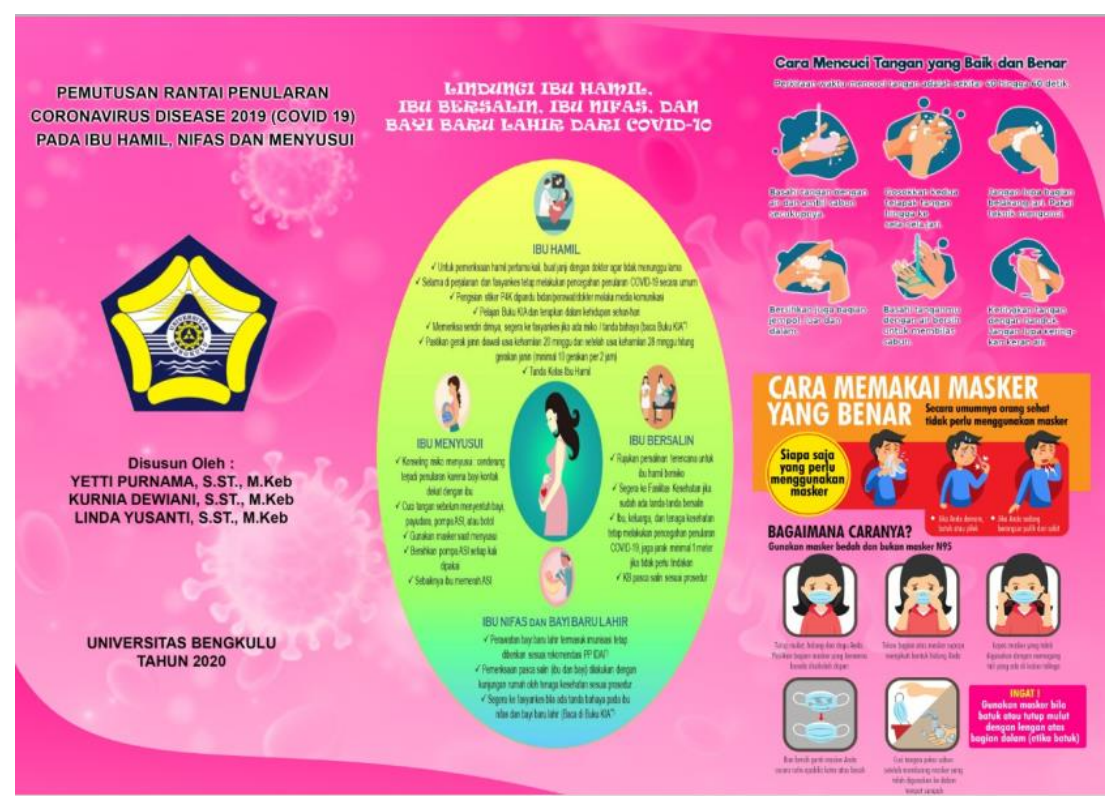

Gambar 1. Media Leaflet

Langkah awal yang dilaksanakan oleh tim pengabdi adalah melakukan observasi atau penjajakan calon mitra melalui wawancara dengan camat Ratu Agung dan bidan koordinator Puskesmas Nusa Indah, Lempuing dan Sawah Lebar yang berada di kecamatan Ratu Agung. Hasil observasi dan wawancara diperoleh informasi banyaknya ibu hamil, nifas dan menyusui yang belum mengetahui cara pencegahan atau pemutusan rantai penularan COVID-19 pada kehamilan dan bayi yang dikandungnya. Karakteristik pendidikan dan ekonomi masyarakat daerah di Kecamatan Ratu Agung masih cukup rendah dikarenakan sebagian besar sebagai ibu rumah tangga yang tidak memiliki pekerjaan sampingan dan suami bekerja sebagai buruh harian lepas atau serabutan, sehingga dalam situasi pademik COVID-19 seperti ini sangat berdampak pada perekonomian keluarga mereka yang akan memengaruhi pemenuhan kebutuhan nutrisi selama kehamilan, nifas dan proses menyusui. Hasil observasi dan wawancara juga didapatkan banyak ibu hamil yang tidak memiliki nomor whatsapp sehingga tidak memungkinkan tim pengabdi untuk memberikan pengetahuan dan evaluasi melalui group whatsapp, sehinga pemberian informasi atau pengetahuan diberikan secara langsung kepada khalayak sasaran dari rumah ke rumah. 


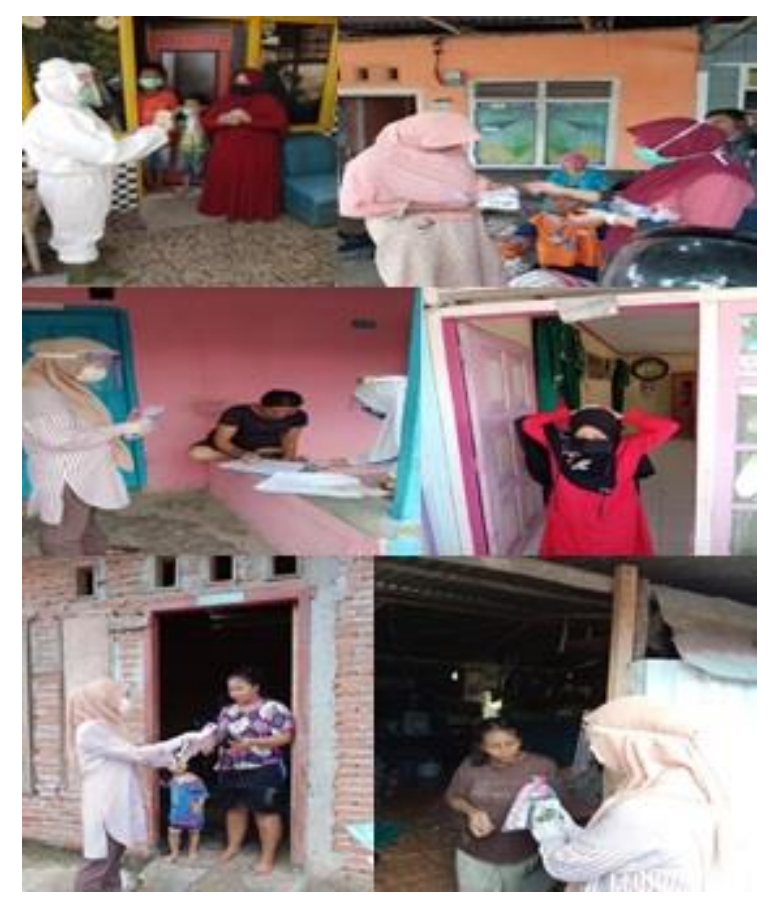

Gambar 2. Pelaksanaan Kegiatan

Kegiatan telah dilaksanakan di wilayah Kecamatan Ratu Agung Kota Bengkulu pada tanggal 20 sd 23 Mei 2020 dan dilanjutkan kembali pada tanggal 26 sd 27 Mei 2020. Dapat dilihat pada Gambar 2.

\section{Diskusi}

Sebelum Kegiatan dilaksanakan, terlebih dahulu dilakukan pretest terhadap khalayak sasaran untuk mengetahui baseline pengetahuan mereka mengenai cara pemutusan rantai penularan COVID-19 pada kehamilan dan bayi yang dikandungnya, pada ibu nifas menyusui dan bayinya. Sebanyak 100 orang ibu hamil, nifas dan menyusui diambil sebagai khalayak sasaran dalam pengabdian ini. Hasil pretest rata-rata $83 \%$ khalayak sasaran mempunyai pengetahuan cukup dan $17 \%$ sudah mempunyai pengetahuan yang baik tentang cara pemutusan rantai penularan COVID-19. Kemudian Tim pengabdi membagikan leaflet dan menjelaskan isi leaflet secara langsung kepada khalayak sasaran, leaflet ini berisi materi tentang cara pemutusan rantai penularan coronavirus disease 2019 (covid-19) pada ibu hamil, nifas dan 
menyusui, yaitu:

1. Cara pencegahan penularan atau melindungi ibu hamil, nifas, menyusui dan bayi dari covid-19

2. Cara mencuci tangan yang benar (6 langkah cuci tangan)

3. Cara memakai masker yang benar

Evaluasi akhir dilakukan 1 bulan kemudian yaitu tanggal 20 Juni 2020, dilakukan secara random dan diambil 10 orang. Evaluasi dengan meminta mereka melakukan teknik cuci tangan dan pemakaian masker dengan benar. Evaluasi ini dilakukan secara langsung kepada tim pengabdi. Hasil posttest pengetahuan meningkat $100 \%$ sasaran bisa melakukan cara mencuci tangan 6 langkah, memakai masker dengan benar. Terlihat dalam Gambar 3. Hal tersebut sesuai dengan langkah-langkah yang dianjurkan oleh Kementerian Kesehatan RI melalui gerakan masyarakat hidup sehat (GERMAS) untuk mencegah penularan pada ibu hamil, nifas dan masa menyusui yaitu:

1. Cuci tangan dengan sabun dan air mengalir sedikitnya selama 20 detik (cara cuci tangan yang benar pada buku KIA hal. 28). Gunakan hand sanitizer berbasis alkohol yang setidaknya mengandung alkohol 70\%, jika air dan sabun tidak tersedia. Cuci tangan terutama setelah Buang Air Besar (BAB) dan Buang Air Kecil (BAK), dan sebelum makan (Buku KIA hal 28 ).

2. Khusus untuk ibu nifas, selalu cuci tangan setiap kali sebelum dan sesudah memegang bayi dan sebelum menyusui. (Buku KIA hal. 28).

3. Hindari menyentuh mata, hidung dan mulut dengan tangan yang belum dicuci.

4. Sebisa mungkin hindari kontak dengan orang yang sedang sakit.

5. Gunakan masker medis saat sakit. Tetap tinggal di rumah saat sakit atau segera ke fasilitas kesehatan yang sesuai, jangan banyak beraktivitas di luar.

6. Tutupi mulut dan hidung saat batuk atau bersin dengan tissue. Buang tissue pada tempat yang telah ditentukan. Bila tidak ada tissue, lakukan batuk sesuai etika batuk.

7. Bersihkan dan lakukan disinfeksi secara rutin permukaan dan benda yang sering disentuh 
8. Menggunakan masker medis adalah salah satu cara pencegahan penularan penyakit saluran napas, termasuk infeksi COVID-19. Akan tetapi penggunaan masker saja masih kurang cukup untuk melindungi seseorang dari infeksi ini, karenanya harus disertai dengan usaha pencegahan lain. Pengunaan masker harus dikombinasikan dengan hand hygiene dan usaha-usaha pencegahan lainnya.

9. Penggunaan masker yang salah dapat mengurangi keefektivitasannya dan dapat membuat orang awam mengabaikan pentingnya usaha pencegahan lain yang sama pentingnya seperti hand hygiene dan perilaku hidup sehat.

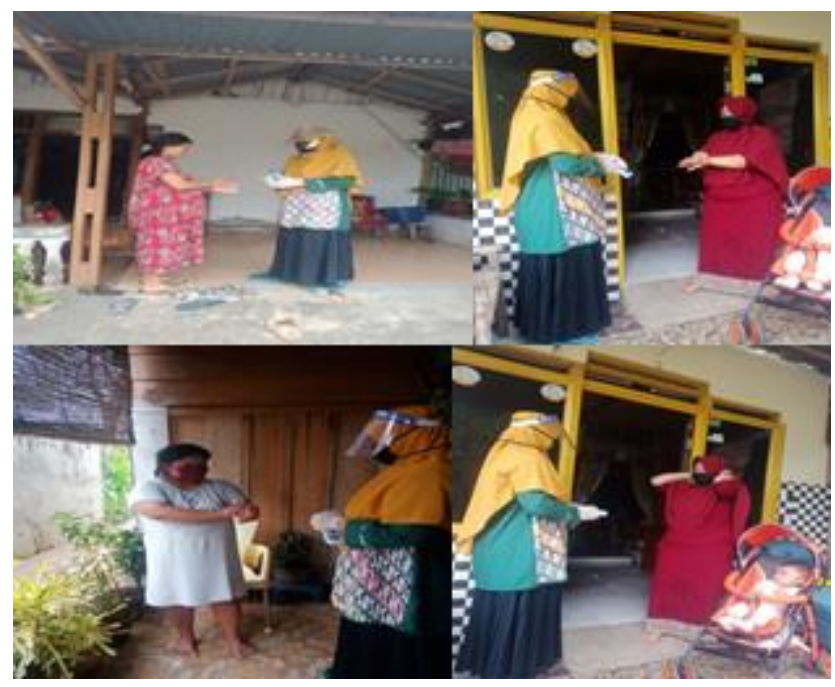

Gambar 3. Evaluasi kegiatan

\section{Kesimpulan}

Para khalayak yaitu ibu hamil, nifas dan menyusui di Kecamatan Ratu Agung Kota Bengkulu memperoleh tambahan pengetahuan dan pemahaman tentang penularan COVID-19, dapat melakukan cuci tangan dengan sabun dan handsanitizer secara benar, memakai dan melepaskan masker yang benar dan minum multivitamin untuk meningkatkan sistim imunitas tubuh, sehingga para khalayak dapat memutuskan rantai penularan COVID-19.

\section{Pengakuan/Acknowledgements}

Ucapan terima kasih kepada masyarakat di Kecamatan Ratu Agung Kota Bengkulu yang telah membantu terlaksananya kegiatan ini serta 
Lembaga Penelitian dan Pengabdian Kepada Masyarakat (LPPM) Universitas Bengkulu melalui PNBP UNIB 2020 dengan nomor kontrak 1512/UN30.15/AM/2020, serta pihak-pihak lain yang telah membantu tim pengabdi dalam proses pengabdian.

\section{Daftar Referensi}

Adrian MCL. 2020. Strategi dan komunikasi promosi kesehatan maternal saat pandemi COVID-19dalam webinar Pelayanan kesehatan maternal di era pandemi covid-19. Malang; HOGSI malang.

Davies A, Anne D, Bennet A. Testing the efficacy of homemade mask: would they protect in an influenza pandemic?, Disaster Mes Public Health Preparedness 2013:7:413-418

Dinkes Kota Bengkulu. 2019. Profil kesehatan kota Bengkulu tahun 2018.

Dinkes Provinsi Bengkulu. 2020. Press release Covid-19. Kamis 09 April 2020.

Kemenkes RI. 2017. Peraturan menteri kesehatan Republik Indonesia Nomor 27 Tahun 2017 Tentang Pedoman PPI. Pencegahan dan Pengendalian Infeksi (PPI).

Kemenkes RI. 2020. Media kesehatan keluarga cegah Covid-19. Jakarta; P2P

Kemenkes RI. 2020. Pedoman bagi ibu hamil, ibu nifas dan bayi baru lahir selama sosial distancing. Jakarta: Dirjend Kesmas.

Kemenkes RI. 2020. Pedoman Pencegahan Pengendalian Coronavirus Disease (COVID-19). Jakarta: Dirjend P2P.

Macintyre, Seale H, Tham DC, Hien DN. A cluster RCT of cloth mask compared with medical mask in healthcare workers, BMJ Open 2015 https://bmjopen.bmj.com/content/5/4/e006577.

POGI. 2020. Rekomendasi penanganan infeksi virus corona (Covid-19) pada maternal (hamil, bersalin dan nifas). Surabaya; Pokja ISR PP POGI

Sande M. Professional and Homemade Facemask reduce exposure to respiratory infections among the general population https://pubmed.ncbi.nlm.nih.gov/18612429.

WHO. 2020. Clinical management of severe acute respiratory infection (SARI) when COVID-19disease is suspected.

WHO. 2020. Getting your workplace ready for COVID-19. :https://www. who.int/coronaviruse. Diakses 27 Februari 2020. 